\title{
Male reproductive system in the South American catfish Conorhynchus conirostris
}

\author{
D. C. J. R. Lopes, N. Bazzoli*, M. F. G. Brito \\ AND T. A. MARIA \\ Graduate Program on Zoology of Vertebrates, Catholic University of Minas Gerais, \\ 30 535-610, Belo Horizonte, MG, Brazil
}

(Received 30 May 2003, Accepted 27 January 2004)

\begin{abstract}
The testes of the catfish Conorhynchus conirostris $(n=67)$ from the São Francisco River, Minas Gerais, Brazil were of the fringed type, similar to those of some Pimelodidae. The germ, Sertoli and Leydig cells showed characteristics which are general for all vertebrates although the spermatozoa had a peculiar morphology, with an ovoid head without an acrosome, inverted U-shaped nucleus, a short midpiece and a long tail, typical of teleosts showing external fertilization. The spermatic duct and genital papilla performed a secretory function.

(C) 2004 The Fisheries Society of the British Isles
\end{abstract}

The Siluriformes form a diverse group of marine and freshwater fishes with about 2000 species (Nelson, 1994). Siluriformes have a varied testicular morphophysiology, with the testes being either spermatogenic only, possessing a spermatogenic cranial region and a secretory caudal region, or showing accessory seminal vesicles (Loir et al., 1989; Santos et al., 2001).

Testicular morphology of Siluriformes is quite variable. The testes may be elongated showing digitiform projections, or fringes (most families of Siluriformes) or may be elongated, with no fringes or projections as in Helogeneidae and Ariidae (Loir et al., 1989).

In the Siluriformes with external fertilization, studies of spermatozoon ultrastructure are available for only a few species: Ictalurus punctatus (Rafinesque) (Poirier \& Nicholson, 1982), Rhamdia sapo (Valenciennes) (Maggese et al., 1984), Heteropneustes fossilis (Bloch) (Nath \& Chand, 1998), Sorubim lima (Bloch \& Schneider) (Quagio-Grassiotto \& Carvalho, 1999) and Iheringichthys labrosus (Lütken) (Santos et al., 2001). Even though the spermatic duct and genital papilla are known to play an important role in the release of spermatozoa and in the dynamics of fertilization, studies on these structures are rare, particularly, in Siluriformes (Rasotto \& Shapiro, 1998).

\footnotetext{
*Author to whom correspondence should be addressed at present address: Av. Dom José Gaspar, 500 Coração Eucarístico Cep: 30.535-610 Brazil. Tel.: +553133194269; fax: +553133194938; email: bazzoli@pucminas.br
} 
The pirá catfish Conorhynchus conirostris (Valenciennes) an endemic fish in the São Francisco River basin, belongs to the order Siluriformes, family Pimelodidae, and may reach up to $100 \mathrm{~cm}$ total length $\left(L_{\mathrm{T}}\right)$ and $13 \mathrm{~kg}$ in body mass (Sato, 1999). It is a migratory fish of commercial importance and is included in the list of the species threatened with extinction in this basin (Lins et al., 1997).

In order to study the testicular morphophysiology and the ultrastructure of the spermatogenic cells, spermatic duct and genital papilla, specimens of pirá were obtained from a commercial fishery from December 1998 to January 2000 in the São Francisco River, near Pirapora, Minas Gerais, Brazil (17²0'45" S; $\left.44^{\circ} 56^{\prime} 55^{\prime \prime} \mathrm{W}\right)$. Males were weighed $(M, \mathrm{~g})$ and killed by decapitation and their reproductive systems $(n=10)$ were removed, weighed $\left(M_{\mathrm{T}}, \mathrm{g}\right)$ and fixed in $10 \%$ formalin for anatomical study. Fragments $(n=67)$ of testes, spermatic duct and genital papilla were fixed in Bouin's liquid, embedded in paraffin or glycol methacrylate, then cut into $3-5 \mu \mathrm{m}$ sections, and stained with haematoxylineosin or $1 \%$ toluidin blue-sodium borate. Fragments $(n=10)$ of testes, spermatic duct and genital papilla were subjected to classical histochemical techniques for the detection of carbohydrates and proteins (Pearse, 1985): Periodic Acid-Schiff (PAS), alcian blue pH 2.5 and $0 \cdot 5$, and Ninhydrin-Schiff. For the ultrastructural study, fragments of the testes, spermatic duct and genital papilla of five specimens were fixed in $2.5 \%$ glutaraldehyde in phosphate buffer $(0 \cdot 1 \mathrm{M}, \mathrm{pH} 7 \cdot 3)$ for $12 \mathrm{~h}$ at $4^{\circ} \mathrm{C}$, then post-fixed in $1 \%$ osmium tetroxide in phosphate buffer $(0 \cdot 1 \mathrm{M})$ for $2 \mathrm{~h}$, and embedded in Epon. Ultrathin sections were cut with a diamond knife in an ultramicrotome SORVALL MT2-B and stained with uranyl acetate and lead citrate and examined under a ZEISS EM-10 transmission electron microscope.

The testes of $C$. conirostris had a small volume and gonado-somatic index $\left(I_{\mathrm{G}}, I_{\mathrm{G}}=100 M_{\mathrm{T}} M^{-1}\right.$ ) always $<0.5 \%$ of body mass, and were paired organs with digitiform projections, or fringes, along their entire length [Fig. 1(a)]. They were located in the coelomic cavity and were dorsally supported by the mesorchia. The fringes communicated with the spermatic duct, located in the central portion of the testis [Fig. 1(b)]. The spermatic ducts of the right and left testes were joined at their caudal portions, forming the common spermatic duct, extending to the genital papilla, situated caudally to the anal opening. The genital papilla was conic, without fringes and lined by simple columnar epithelium. The testes were surrounded by a tunica albuginea of connective tissue, that emitted septa to the interior of the organ, delimiting seminiferous tubules made up of spermatocysts [Fig. 1(c)]. Within each spermatocyst, germ cells were at the same stage of development [Fig. 1(d)]. The walls of the spermatocysts were formed by cytoplasmic processes of Sertoli cells.

Despite their fringed morphology, the testes of $C$. conirostris are similar histologically to most teleosts, with spermatogonia distributed along the seminiferous tubules and spermatogenic activity along their entire length; that is, an unrestricted testis type as described by Grier (1981). In contrast to I. labrosus (Santos et al., 2001), the caudal region of the testes of $C$. conirostris is not secretory. In the present study, seminal vesicles or accessory glandular structures were not observed in the reproductive system as in some Siluriforms (Loir et al., 1989). 

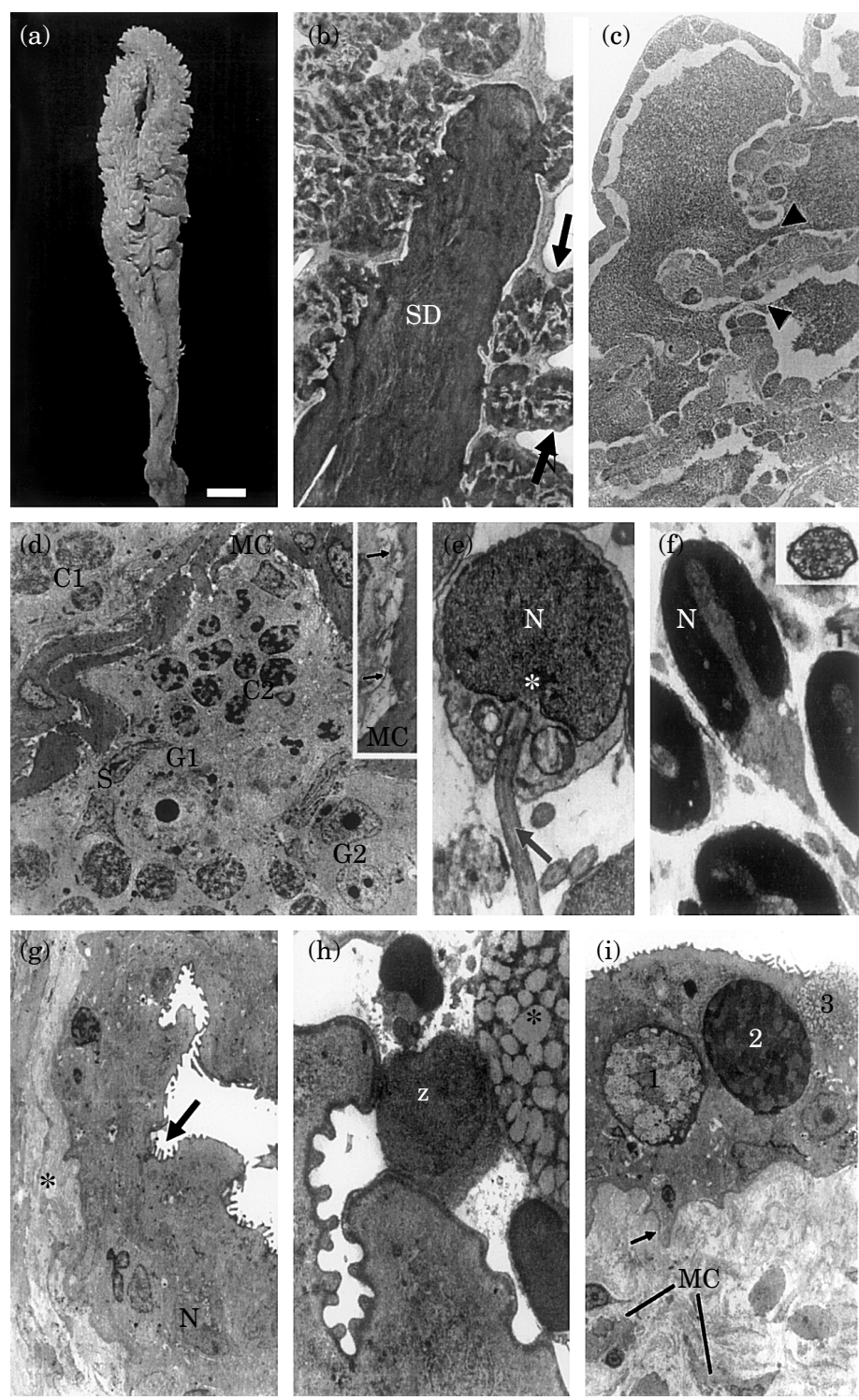

FIG. 1. Organization of male reproductive system of $C$. conirostris. (a) Gross morphology of fringed testis. $\mathrm{x} 1 \cdot 3$. Scale bar $=1 \mathrm{~cm}$. (b) Cross-section of testis showing digitiform projections $(\rightarrow)$ and spermatic duct (SD) filled with spermatozoa. Haematoxylin-eosin; x50. (c) Testicular fringe showing anastomosis ( ) between seminiferous tubules. Toluidine blue-sodium borate; x100. (d) Ultrastructure of germ cells: primary spermatogonia $(\mathrm{G} 1)$, secondary spermatogonia $(\mathrm{G} 2)$, primary spermatocytes $(\mathrm{C} 1)$ and secondary spermatocytes (C2); MC, myoid cells; S, Sertoli cells. x2400. Inset: collagen fibrils $(\rightarrow)$ attached to plasma membrane of the myoid cells (MC). x5000. (e) Spermatids with condensed nucleus $(\mathrm{N})$, implantation fossa $(*)$ and flagellum $(\rightarrow)$. x14250. (f) Longitudinal section of spermatozoa with inverted U-shaped nucleus $(\mathrm{N})$ in the head, and short midpiece. x12750. Insert: ultrastructure of flagellum showing microtubules in $9+2$ axonemal arrangement. x26600. (g) Ultrastructure of spermatic duct showing epithelial cells with microvilli $(\rightarrow)$ and nucleus $(\mathrm{N})$ supported by a lamina propria $(*)$ with collagen fibrils and myoid cells. x1615. (h) Spermatozoa (Z) and secretory vesicles $(*)$ in the spermatic duct. x11.000. (i) Ultrastructure of genital papilla with mucous cells at different functional stages (1, 2 and 3); $\rightarrow$, basement membrane; MC, myoid cells. x1715. 
In $C$. conirostris, the myoid cells had an elongated shape with a fusiform nucleus, they were arranged in discontinuous, concentric layers around the seminiferous tubules [Fig. 1(d)] and showed electron-dense regions on the inner side of the plasma membrane forming macular junction contacts with other cell types in the testis. In addition, collagen fibrils appeared to attach to the plasma membrane of the myoid cells [Fig. 1(d); inset], similar to those described in Esox lucius L. and Esox niger Lesueur (Grier et al., 1989). The myoid cells contained a cytoplasm rich in microfibrils and they may contribute to the spermiation process as observed by Yaron (1995) and Santos et al. (2001).

During spermiogenesis, the early spermatids, with a scant cytoplasm and a nucleus in condensation process [Fig. 1(e)], gradually differentiated into spermatozoa, with an ovoid head, no acrosome, a short midpiece and a long flagellum with a $9+2$ axonemal arrangement [Fig. 1(f); inset]. In the head, condensed chromatin with an inverted U- or horseshoe-shape, and a deep penetration of the nuclear fossa were visible [Fig. 1(f)]. The single flagellum had scant cytoplasm surrounded by a cytoplasmic membrane, without lateral fins. These characteristics are typical of primitive spermatozoa of fishes with external fertilization (Billard, 1969). According to the classification proposed by Jamieson (1991), the sperm morphology of C. conirostris corresponds to the simple type called aquasperm, which has a round or ovoid head and short midpiece containing few mitochondria. In addition to these morphological features that are common to the spermatozoa of many teleosts, inverted U- or horseshoeshaped chromatin and a deep nuclear fossa were also observed in the siluriform Heteropneustes fossilis (Bloch) (Nath \& Chand, 1998) and in the tetraodontiform Balistes forcipatus (Gmelin) (Jamieson, 1991). This type of nuclear fossa, which penetrates almost to the tip of the nucleus constitutes a divergence from the common teleost sperm ultrastructure, as has been reported by QuagioGrassiotto et al. (2001). The spermatozoa of $C$. conirostris had a single flagellum as in most species of teleosts but some were biflagellated, as in $R$. sapo (Maggese et al., 1984). The pirá sperm tail does not have flagellar fins as is common in sperm of others siluroids and gymnotoids, providing weak support for a close relaionship between Siluriformes, Cypriniformes and Characiformes (Jamieson, 1991). The acrosome-less head in the spermatozoa of C. conirostris is a common characteristic in teleosts, related to external fertilization and the presence of micropyle in the eggs (Jamieson, 1991).

During spermiation, the spermatocysts released mature sperm and the seminiferous tubules had compartments that looped at the testis periphery forming a continuously anastomosing tubular system [Fig.1(c)], connecting to the spermatic duct, similar to the observations of Grier (1993). The wall of the spermatic duct was lined by secretory prismatic cells with microvilli and a lamina propria made up of myoid cells and collagen fibrils [Fig. 1(g)]. The lumen of the common spermatic duct may have contained residual spermatozoa after spermiation and the cells lining the lumen may have contained secretory vesicles [Fig. 1(h)]. According to Billard \& Takashima (1983) and Rasotto \& Shapiro (1998), the spermatic duct may participate in the transport of spermatozoa, in the secretion of substances that form the seminal fluid, and in the reabsortion of residual spermatoza. 
The sperm are released into the spermatic duct upon spermiation and subsequently pass through the sperm duct, which itself passes through the genital papilla whose wall consisted of simple columnar epithelium with microvilli and mucous cells at different functional stages [Fig. 1(i)]. Myoid cells and collagen fibrils were abundant in the lamina propria of the genital papilla [Fig. 1(i)]. Positive reactions to PAS, Ninhydrin-Schiff and alcian blue ( $\mathrm{pH} 2.5$ and 0.5 ) indicated that the mucous cells contained neutral glycoproteins associated with carboxylated acid glycoconjugates. Histological and histochemistry evidence in the present study suggest that mucous cells may be involved in secretory activity and myoid contractile cells could participate in the release of gametes, as reported in other species (Rasotto \& Shapiro, 1998; Richtarski \& Patzner, 2000). Besides genital papilla, positive reactions to PAS were also observed in the basal membrane of the seminiferous tubules, in the basal membrane situated between connective tunica and the cysts, and in secretions presented in the lumen of the seminiferous tubules.

The fringed testicular morphology of $C$. conirostris without seminal vesicles or accessory glandular structures is similar to those observed in the pimelodid Pseudoplatystoma corruscans (Spix \& Agassiz) (Brito \& Bazzoli, 2003).

We wish to thank CNPq/PADCT/CIAMB III (62.0088/98-2), CNPq (479733/01), FIP PUC Minas (99/02-P) and FAPEMIG for their financial support; CAPES for the master's degree scholarship granted; to the Electron Microscopy Centre CEMEL/ UFMG; IEF-MG and IBAMA for their technical support; fishermen of Pirapora and Buritizeiro, for help in the field collection, to R.J. Young for suggestions on the English version, and to J. Enemir dos Santos for a testis photograph.

\section{References}

Billard, R. (1969). La espermatogênese de Poecilia reticulata. I. Estimation du nombre de générations goniales et rendement de la spermatogênese. Annales de Biologie Animale, Biochimie, Biophysique 9, 251-271.

Billard, R. \& Takashima, F. (1983). Resorption of spermatozoa in the sperm duct of rainbow trout during the post-spawning period. Bulletin of the Japanese Society of Scientific Fisheries 49, 387-392.

Brito, M. F. G. \& Bazzoli, N. (2003). Reproduction of the surubim catfish (Pisces, Pimelodidae) in the São Francisco river, Pirapora region, Minas Gerais, Brazil. Arquivo Brasileiro de Medicina Veterinária e Zootecnia 55, 457-466.

Grier, H. J. (1981). Cellular organization of the testis and spermatogenesis in fishes. American Zoology 21, 345-357.

Grier, H. J. (1993). Comparative organization of Sertoli cells including the Sertoli cell barrier. In The Sertoli Cell (Russell, L. D. \& Griswold, M. D., ed.), pp. 703-739. Clearwater, FL: Cache River Press.

Grier, H. J., van den Hurk, R. \& Billard, R. (1989). Cytological identification of cell types in the testis of Esox lucius and E. niger. Cell Tissue Research 257, 491-496.

Jamieson, B. G. M. (1991). Fish Evolution and Systematics: Evidence from Spermatozoa. Cambridge: Cambridge University Press.

Lins, L. V., Machado, A. B. M., Costa, C. M. R. \& Herrmann, G. (1997). A Guidebook for Elaboration for Endangered Species Lists: with the Official List for the Fauna of Minas Gerais. Belo Horizonte: Fundação Biodiversitas (in Portuguese).

Loir, M., Cauty, C., Planquette, P. \& Bail, P. Y. (1989). Comparative study of the male reproductive tract in seven families of South American catfishes. Aquatic Living Resources 2, 45-56. 
Maggese, M. C., Cukier, M. \& Cussac, V. E. (1984). Morphological changes, fertilizing ability and motility of Rhamdia sapo (Pisces, Pimelodidae) sperm induced by media of different salinities. Revista Brasileira de Biologia 44, 541-546.

Nath, A. \& Chand, B. (1998). Ultrastructure of spermatozoa correlated with phylogenetic relationship between Heteropneustes fossilis and Rana tigrina. Cytobios 95, $161-165$

Nelson, J. S. (1994). Fishes of the World. New York: John Wiley \& Sons.

Pearse, A. G. E. (1985). Histochemistry: Theoretical and Applied. Edinburgh: Churchill Livingstone.

Poirier, G. R. \& Nicholson, N. (1982). Fine structure of the testicular spermatozoa from the channel catfish, Ictalurus punctatus. Journal of Ultrastructure Research 80, $104-110$.

Quagio-Grassiotto, I. \& Carvalho, E. D. (1999). The ultrastructure of Sorubim lima (Teleostei, Siluriformes, Pimelodidae) spermatogenesis: premeiotic and meiotic periods. Tissue \& Cell 31, 561-567.

Quagio-Grassiotto, I., Oliveira, C. \& Gosztonyi, A. E. (2001). The ultrastructure of spermiogenesis and spermatozoa in Diplomystes mesembrinus. Journal of Fish Biology 58, 1623-1632. doi: 10.1006/jfbi.2001.1572.

Rasotto, M. B. \& Shapiro, D. Y. (1998). Morphology of gonoducts and male genital papilla, in the bluehead wrasse: implications and correlates on the control of gamete release. Journal of Fish Biology 52, 716-725. doi: 10.1006/jfbi.1997.0615.

Richtarski, U. \& Patzner, R. A. (2000). Comparative morphology of male reproductive systems in Mediterranean blennies (Blenniidae). Journal of Fish Biology 56, 22-36. doi: $10.1006 /$ jfbi.1999.

Santos, J. E., Bazzoli, N., Rizzo, E. \& Santos, G. B. (2001). Morphofunctional organization of the male reproductive system of the catfish Iheringichthys labrosus (Lutken, 1874) (Siluriformes: Pimelodidae). Tissue \& Cell 33, 533-540.

Sato, Y. (1999). Reproduction of São Francisco river basin fishes: induction and characterization of patterns. PhD Thesis, Federal University of São Carlos, SP, Brazil (in Portuguese).

Yaron, Z. (1995). Endocrine control of gametogenesis and spawning induction in the carp. Aquaculture 129, 49-73. 